\title{
Status Padang Lamun Pantai-Pantai Wisata di Pacitan
}

\author{
NURUL KUSUMA DEWI ${ }^{1}$, SIGIT ARI PRABOWO ${ }^{1}$ \\ ${ }^{1}$ Program Studi Pendidikan Biologi, FPMIPA, IKIP PGRI MADIUN \\ Jl. Setiabudi No. 85 Madiun 63118 \\ email: seagrass_nurul@yahoo.co.id
}

\begin{abstract}
The purpose of this research was to study the condition of seagrass communities at Pacitan coast. The study was conducted at Klayar, Srau, Teleng Ria, Pancer, Tawang, and Pidakan at Pacitan coast. The presence of seagrass communities was determined by the physical and chemical factors. Data were collected using quadrate plots with five transects. At each transect, data was collected using the quadrate plot, $0.5 \mathrm{~m}$ x $0.5 \mathrm{~m}$, with 11 replications. On each plot, number of species, density, and their coverage were measured. Water quality such as light penetration, water level, current velocity, salinity, temperature, wave height, $\mathrm{DO}, \mathrm{pH}$, sediment texture, and nutrients of $\mathrm{NH}_{4}, \mathrm{NO}_{3}$, $\mathrm{PO}_{4}, \mathrm{C}$-organic were also measured. The results showed, from 6 beaches studied, seagrass is only found in Tawang and Pidakan. There were 3 species of seagrass in Tawang beach, i. e Cymodocea serrulata, Thalassia hemprichii, and Halophila ovalis which were distributed unevenly, with 37,66 \% coverage. In Pidakan beach, there is 1 species of seagrass, Thalassia hemprichii, with 30,89\% coverage. These variations were due to the physical and chemical factors in each location. $T$. hemprichii was the seagrass species which was tolerant to changes in environmental conditions. Light and substrate were as important factors that determined the presence and abundance of seagrass communities in Pacitan coastal waters.
\end{abstract}

Keywords: coverage, light, seagrass, substrate, tolerant species

\section{PENDAHULUAN}

Lamun merupakan salah satu sumber daya pesisir Indonesia yang bernilai ekologis dan ekonomis. Padang lamun tergolong dalam ekosistem laut yang paling produktif dan mempunyai peran penting dalam dinamika nutrien pesisir. Selain itu padang lamun juga berhubungan dengan perolehan perikanan lokal, dan ekosistem tetangganya, seperti terumbu karang (Goltenboth et al. 2012). Di Indonesia terdapat 13 spesies lamun yang tergolong dalam 7 genus. Spesies terkini ditemukan adalah Halophila sulawesii, di kepulauan Spermonde barat daya Sulawesi (Kuo 2007).

Ada dua tipe ekosistem padang lamun, yaitu padang lamun yang secara permanen terendam dan padang lamun yang terpapar dan tidak terendam saat air laut surut. Sejumlah lamun yang terdapat pada kedua tipe tersebut mengembangkan dua morfotipe yang berbeda. Ada zonasi yang spesifik pada komunitas lamun intertidal. Selain itu, lamun juga mempunyai ciri-ciri sebagai berikut yaitu tidak ada stomata, mempunyai kutikula yang tipis, perkembangan schizogenous dari sistem lakunar, pollinasi yang hidrofil, dan tidak ada diafragma pada sistem lakunar (Goltenboth et al. 2012). Distribusi dan stabilitas komunitas lamun ditentukan oleh faktor-faktor antara lain: nutrien, cahaya, sedimen, salinitas, dan suhu (Papathanasiou et al. 2015; Kilminster et al. 2014; Koch et al. 2007; Moreno et al. 2014; Kaldy et al. 2015).

Pacitan merupakan salah satu kabupaten di Jawa Timur yang memiliki potensi sumber daya alam laut yang luar biasa. Terdapat sekitar 18 pantai di Pacitan dengan karakteristik bervariasi. Pantai-pantai tersebut adalah Pantai Banyu Tibo, Buyutan, Karang Bolong, Klayar, Sruni, Srau, Watukarung, Teleng Ria, Tamperan Gung, Kali Uluh, Wawaran, Pidakan, Soge, Tawang, Taman, Kunir, Teluk Bawur dan Pantai Pancer. Pacitan memiliki potensi keanekaragaman sumber daya hayati laut termasuk padang lamun yang belum teridentifikasi dengan baik. Berdasarkan komunikasi dengan warga, 
potensi padang lamun Pacitan terletak di Pantai Tawang dan Pantai Srau. Minimnya informasi tentang padang lamun akan menyulitkan pengelolaan dan usaha konservasinya. Informasi tentang status padang lamun mutlak diperlukan untuk pengelolaan padang lamun secara lestari dan berkelanjutan. Penelitian ini diharapkan juga akan memberikan informasi kepada pihakpihak terkait tentang manfaat ekosistem padang lamun sebagai penunjang produksi perikanan dan peruntukan lainnya, sehingga kelestarian ekosistem padang lamun di masa mendatang akan lebih diperhatikan.

Penelitian ini bertujuan untuk mempelajari status padang lamun pantaipantai wisata di Pacitan. Secara spesifik, akan dipelajari kondisi padang lamun melalui parameter-parameter: spesies-spesies lamun yang hadir dan mendominasi, densitas, dan persen penutupan lamun di Pantai Klayar, Pancer, Srau, Teleng Ria, Watu Karung, dan Tawang. Di samping itu, juga dipelajari kualitas air meliputi kecerahan, tinggi muka air, kecepatan arus, salinitas, suhu, tinggi ombak, DO, $\mathrm{pH}$, tekstur sedimen dan nutrien berupa $\mathrm{NH}_{4}, \mathrm{NO}_{3}, \mathrm{PO}_{4}, \mathrm{C}$-organik di masingmasing lokasi.

\section{METODE}

Lokasi kajian adalah Pantai Klayar, Srau, Teleng Ria, Pancer, Tawang, dan Pantai Pidakan Kabupaten Pacitan. Penelitian dilakukan pada bulan Nopember 2014 - April 2015. Metode yang digunakan adalah Metode Transek dan Petak Contoh (Transect Plot) yaitu metode pencuplikan contoh populasi suatu komunitas dengan pendekatan petak contoh yang berada pada garis yang ditarik melewati wilayah ekosistem tersebut. Penelitian dilakukan dengan meletakkan 5 transek (masing-masing $50 \mathrm{~m}$ ) tegak lurus garis pantai. Jarak antar transek $25 \mathrm{~m}$. Pada setiap transek diletakkan plot berukuran 50x50 $\mathrm{cm}$ dengan jarak antar plot $5 \mathrm{~m}$. Pada setiap plot diidentifikasi setiap jenis tumbuhan lamun yang ada dan dicatat persen penutupannya. Diukur tinggi kanopi. Dicatat semua organisme lain yang ditemukan dalam plot. Diambil contoh lamun dari tiap spesies yang ada untuk dibuat herbarium. Faktor-faktor fisiko kimia yang diukur meliputi: kecerahan, temperatur, salinitas, $\mathrm{pH}$, kecepatan arus perairan dan nutrien berupa $\mathrm{NH}_{4}, \mathrm{NO}_{3}, \mathrm{P}_{2} \mathrm{O}_{5}$, $\mathrm{C}$ organik, bahan organik.

\section{HASIL}

Tabel 1. Jenis-Jenis Lamun yang Ditemukan di Lokasi Kajian

\begin{tabular}{c|l|c|c|c|c}
\hline No. & Lokasi Kajian & Familia & Sub Familia & Genus & Species \\
\hline 1. & Pantai Klayar & - & - & - & - \\
\hline 2. & Pantai Srau & - & - & - & - \\
\hline 3. & $\begin{array}{l}\text { Pantai Teleng } \\
\text { Ria }\end{array}$ & - & - & - & - \\
\hline 4. & Pantai Pancer & - & - & - & \multicolumn{1}{c}{-} \\
\hline 5. & Pantai Tawang & $\begin{array}{l}\text { Potamogetonaceae } \\
\text { Hydrocharitaceae }\end{array}$ & $\begin{array}{l}\text { Cymodoceoideae } \\
\text { Thalassiodae } \\
\text { Halophiloideae }\end{array}$ & $\begin{array}{l}\text { Cymodocea } \\
\text { Thalassia } \\
\text { Halophila }\end{array}$ & $\begin{array}{l}\text { 1. C. rotundata } \\
\text { 2. T. hemprichii } \\
\text { 3. H. ovalis }\end{array}$ \\
\hline 6. & Pantai Pidakan & Hydrocharitaceae & Thalassiodae & Thalassia & 1. T. hemprichii \\
\hline
\end{tabular}

Hasil penelitian menunjukkan, dari 6 pantai yang diteliti, lamun hanya ditemukan di Pantai Tawang dan Pantai Pidakan. Kekayaan jenis lamun di Pantai Tawang sebanyak tiga jenis, dengan komposisi jenisnya pada Tabel 1. Berdasarkan kekayaan jenis lamun yang lebih dari satu jenis tersebut, maka komunitas lamun di Pantai Tawang berupa vegetasi campuran. Sedangkan di Pantai Pidakan, hanya ditemukan satu jenis lamun yaitu Thalassia hemprichii. Berdasarkan kekayaan jenis lamun yang terdiri dari satu jenis tersebut, maka komunitas lamun di Pantai Pidakan berupa vegetasi tunggal. 
Tabel 2. Data Persentase Penutupan Lamun Pantai Tawang dan Pantai Pidakan

\begin{tabular}{cccc}
\hline \multicolumn{2}{c}{ Pantai Tawang } & \multicolumn{2}{c}{ Pantai Pidakan } \\
\hline Transek & $\begin{array}{c}\text { C (persentase } \\
\text { penutupan) }\end{array}$ & Transek & $\begin{array}{c}\text { C (persentase } \\
\text { penutupan) }\end{array}$ \\
\hline I & $15 \%$ & I & $22,14 \%$ \\
\hline II & $28,33 \%$ & II & $52,86 \%$ \\
\hline III & $50,63 \%$ & III & $39,14 \%$ \\
\hline IV & $56,67 \%$ & IV & $15 \%$ \\
\hline V & $37.66 \%$ & V & $25,33 \%$ \\
\hline Rata-rata & $37,66 \%$ & Rata-rata & $30,89 \%$ \\
\hline
\end{tabular}

Tabel 3. Status Padang Lamun

\begin{tabular}{ccc}
\hline & Kondisi & Penutupan (\%) \\
\hline Baik & Kaya/sehat & $\geq 60$ \\
\hline Rusak & Kurang kaya/kurang sehat & $30-59,9$ \\
\cline { 2 - 3 } & Miskin & $\leq 29,9$ \\
\hline
\end{tabular}

Tabel 4. Kondisi Fisiko Kimia Perairan Pantai-Pantai Wisata di Pacitan

\begin{tabular}{rlccccccc} 
No. & \multicolumn{1}{c}{ Parameter } & Satuan & Klayar & Srau & $\begin{array}{c}\text { Teleng } \\
\text { Ria }\end{array}$ & Pancer & Tawang & Pidakan \\
1. & Kecerahan & $\mathrm{m}$ & 2 & 2 & 1.5 & 1.2 & 1.5 & 2.5 \\
\hline 2. & Temperatur udara & ${ }^{0} \mathrm{C}$ & 24 & 24 & 25 & 28 & 24 & 28 \\
\hline 3. & Temperatur air & ${ }^{0} \mathrm{C}$ & 27 & 28 & 29 & 30 & 28 & 32 \\
\hline 4. & Salinitas & $0 / 00$ & 35 & 35 & 35 & 35 & 35 & 39.56 \\
\hline 5. & DO & & 7.7 & 8.5 & 7.8 & 9.6 & 7.6 & 6.4 \\
\hline 6. & $\mathrm{pH}$ & - & 7.9 & 8.5 & 8.85 & 8.2 & 11,8 & 7.795 \\
\hline 7. & Kecepatan arus & $\mathrm{m} / \mathrm{s}$ & 0.1 & 0.1 & 0.09 & 0.08 & 0,06 & 0.125 \\
& perairan & & & & & & & \\
8. & $\mathrm{NH}_{4}$ & $\mathrm{me} / 1$ & 0.0 .129 & 0.254 & - & - & 0.130 & 0.075 \\
\hline 9. & $\mathrm{NO}_{3}$ & $\mathrm{me} / 1$ & 0.037 & 0.066 & - & - & 0.109 & 0.04285 \\
\hline 10. & $\mathrm{P}_{2} \mathrm{O}_{5}$ & $\mathrm{ppm}$ & 2.00 & 2.13 & - & - & 4.11 & 0.135 \\
\hline 1. & $\mathrm{C}$ organik & $\%$ & 0.010 & 0.060 & - & - & 0.167 & 0.40 \\
\hline 12. & Bahan organik & $\%$ & 0.016 & 0.103 & - & - & 0.288 & 0.69 \\
\hline
\end{tabular}

\section{PEMBAHASAN}

Jenis-jenis lamun yang ditemukan di Pantai Tawang Pacitan tergolong ke dalam dua familia yaitu Potamogetonaceae dan Hydrocharitaceae (Tabel 1). Sedangkan di Pantai Pidakan, hanya ditemukan satu jenis lamun yaitu Thalassia hemprichii. Sementara di pantai yang lain tidak ditemukan lamun. Jenis Thalassia, Cymodocea dan Halophila, merupakan jenis-jenis lamun yang sering ditemukan dengan kepadatan yang cukup tinggi di beberapa kawasan Indonesia.

Jenis lamun yang sama mempunyai kenampakan bentuk tumbuh (terutama daun dan rimpang tegak) yang berbeda apabila tumbuh pada habitat yang berlainan. Hasil pengamatan menunjukkan, lamun yang tumbuh di Pantai Pidakan ukurannya lebih kecil daripada yang ditemukan di Pantai Tawang, Pacitan. Lamun yang tumbuh pada dasar pasir dan puing karang dengan air yang jernih mempunyai ukuran daun yang lebih kecil dan rimpang tegak yang lebih pendek daripada lamun yang tumbuh pada dasar lumpur yang berair keruh.

Kondisi padang lamun pada suatu lokasi tertentu dalam waktu tertentu dapat dinilai dengan menggunakan persentase luas tutupan. Berdasarkan hasil pengukuran di lokasi penelitian dan hasil perhitungan, didapatkan nilai $\mathrm{C}$ rata-rata di Pantai Tawang sebesar $37,66 \%$ dan di Pantai Pidakan sebesar 30,89 \%. Berdasarkan Keputusan Menteri Negara Lingkungan Hidup No.200 tahun 2004 nilai 
tersebut berarti kondisi padang lamun Pantai Tawang dan Pantai Pidakan termasuk kategori kurang kaya/kurang sehat.

Bila dibandingkan dengan dengan beberapa lokasi lain di kawasan Indonesia Timur (Laut Flores dan Lombok Selatan), penutupan lamun di Pantai Tawang dan Pantai Pidakan memang tergolong kecil. Tetapi bila dibandingkan dengan beberapa tempat di Jawa (misalnya Pantai Sowan Tuban) sudah termasuk bagus. Faktor-faktor yang menjadi penyebab kurang kayanya presentase penutupan lamun di Pantai Tawang, selain karena faktor alami, juga karena semakin meningkatnya aktivitas manusia dan tingginya kegiatan perahu-perahu nelayan di kawasan ini, sehingga kekeruhan sulit dihindarkan. Nelayan-nelayan tersebut menjual hasil lautnya ke TPI Tawang. Kekeruhan bisa disebabkan adanya pergolakan di atas permukaan air oleh seringnya aktivitas perahu nelayan. Seperti diketahui bahwa tingginya tingkat kekeruhan akan menghambat masuknya sinar matahari, sehingga kurang maksimal untuk fotosintesis. Menurunnya fotosintesis berarti mengurangi pertumbuhan lamun.

Faktor-faktor yang sangat mempengaruhi penyebaran lamun di Pantai Pidakan adalah substrat atau sedimen, kedalaman, dan ombak. Tekstur sedimen mempengaruhi pertumbuhan dan kelangsungan hidup lamun. Substrat Pantai Pidakan didominasi oleh karang mati. Hanya spesies tertentu dan berakar kokoh yang mampu tumbuh di habitat tersebut. Komposisi sedimen atau substrat juga mempengaruhi ketersediaan fosfat. Pada sedimen karbonat (mineral sedimen berasal dari terumbu karang), fosfat berinteraksi dengan karbonat dan kurang tersedia sebagai fosfat bebas. Di padang lamun, hal tersebut mungkin menyebabkan fosfor terbatas (Kilminster et al. 2014; Papathanasiou et al. 2015). Tetapi hal ini masih terbantu oleh kelebihan lamun yang dapat mengambil zat hara seperti amonia dan fosfat melalui daun walaupun konsentrasi hara pada kolom air pada umumnya sangat rendah.

Faktor pembatas berikutnya adalah kedalaman. Di Pantai Pidakan, lamun hanya tumbuh pada daerah dangkal berupa rataan terumbu (puing karang mati). Distribusi lamun di pantai tersebut terbatas pada jarak $\pm 50 \mathrm{~m}$ dari garis pantai. Setelah jarak tersebut, kedalaman langsung meningkat drastis. Hal inilah yang menyebabkan lamun tidak lagi ditemukan, karena sinar matahari tidak dapat menjangkau sampai ke dasar sehingga menghalangi lamun melakukan proses fotosintesis.

Faktor lain yang juga menjadi pembatas pertumbuhan lamun di Pantai Pidakan adalah ombak yang kuat. Arus pasang surut yang kuat menyebabkan lamun sulit menancapkan akarnya pada dasar perairan sehingga kurang berkembang-biak dengan baik. Ombak yang kuat juga membuat vegetasi lamun dapat tercabut dari substratnya. Daun lamun yang bersih dari algae epifitik menunjukkan arus setempat relatif kuat. Peningkatan aktivitas manusia berupa kunjungan wisata dan pembangunan mercusuar diharapkan tidak mengganggu pertumbuhan lamun di pantai ini.

Seperti yang telah disebutkan sebelumnya, distribusi dan stabilitas komunitas lamun ditentukan oleh faktor-faktor antara lain: nutrien, cahaya, sedimen, salinitas, dan suhu (Papathanasiou et al. 2015; Kilminster et al. 2014; Koch et al. 2007; Moreno et al. 2014; Kaldy et al. 2015). Hasil pengukuran faktor-faktor fisiko kimia ditunjukkan pada Tabel 4.

Hasil pengukuran menunjukkan bahwa nilai kecerahan Pantai Tawang cukup rendah, berkebalikan dengan nilai kecerahan perairan Pidakan yang cukup tinggi. Intensitas cahaya tertentu penting bagi lamun untuk melakukan proses fotosintesis (Ralph et al. 2007). Berkurangnya penetrasi cahaya ke perairan lamun selain disebabkan oleh eutrofikasi juga dapat disebabkan oleh meningkatnya muatan sedimen (Hauxwell et al. 2006; Ralph et al. 2007; Christianen et al. 2011). Di Pantai Tawang, meningkatnya muatan sedimen disebabkan aktivitas perahu nelayan.

Spesies-spesies lamun menyebar luas secara geografis, hal ini mengindikasikan adanya kisaran toleransi yang lebar terhadap temperatur. Hasil pengukuran menunjukkan, temperatur udara Pantai Tawang sebesar $24^{\circ} \mathrm{C}$ dan temperatur air permukaan sebesar $28^{\circ} \mathrm{C}$, 
sementara di Pantai Pidakan, temperatur udara sebesar $28^{\circ} \mathrm{C}$ dan temperatur air permukaan sebesar $32^{0} \mathrm{C}$ (Tabel 4). Walaupun nilai tersebut sedikit diatas temperatur optimal tetapi penelitian Campbell et al. (2006) menunjukkan, beberapa spesies lamun tropis, Cymodocea rotundata, $C$. serrulata, Halodule uninervis dan Thalassia hemprichii lebih toleran terhadap tekanan suhu, bahkan mampu menoleransi suhu hingga $40^{\circ} \mathrm{C}$, dibandingkan Halophila ovalis, Zostera capricorni dan Syringodium isoetifolium. Temperatur permukaan dipengaruhi oleh kondisi meteorologi dan musim. Pada saat penelitian, di perairan Pantai Tawang dan Pidakan, temperatur air permukaan yang terukur relatif tinggi. Ini terjadi karena pada musim-musim pancaroba, angin biasanya lemah hingga proses pemanasan di permukaan dapat terjadi dengan lebih kuat.

Spesies-spesies lamun memiliki toleransi terhadap salinitas yang berbeda-beda, namun sebagian besar memiliki kisaran toleransi yang lebar terhadap salinitas yaitu antara 10-65 psu (Kaldy et al. 2015; Moreno et al. 2014; Koch et al. 2007). Ini berarti, nilai salinitas di Pantai Tawang dan Pidakan masih berada dalam kisaran toleransi lamun. Pada kondisi sangat hyposaline $(<10 \%)$ atau hypersaline $(>45 \%$ ) , sebagian jenis lamun mengalami tekanan dan mungkin mengalami nekrotik dan kematian sementara sebagian jenis yang lain masih dapat mentoleransi.

Oksigen terlarut adalah kandungan oksigen yang terlarut dalam perairan yang merupakan suatu komponen utama bagi metabolisme organisme perairan yang digunakan untuk pertumbuhan, reproduksi, dan kesuburan lamun. Nilai kandungan oksigen terlarut (DO) perairan padang lamun selalu berfluktuasi. Berfluktuasinya kandungan oksigen terlarut di suatu perairan diduga disebabkan pemakaian oksigen terlarut oleh lamun untuk respirasi akar dan rimpang, respirasi biota air dan pemakaian oleh bakteri nitrifikasi dalam proses siklus nitrogen di padang lamun (Felisberto et al. 2015). Nilai kandungan oksigen terlarut (DO) yang terukur di Pantai Tawang dan Pidakan masih berada dalam jumlah yang cukup untuk pertumbuhan lamun.

Derajat keasaman $(\mathrm{pH})$ mempunyai pengaruh yang sangat besar terhadap organisme perairan sehingga dipergunakan sebagai petunjuk untuk menyatakan baik buruknya suatu perairan. Derajat keasaman $(\mathrm{pH})$ perairan sangat dipengaruhi oleh dekomposisi tanah dan dasar perairan serta keadaan lingkungan sekitarnya. Beberapa penelitian menunjukkan, di banyak tempat $\mathrm{pH}$ yang sangat basa masih dapat ditolerir lamun. Ini berarti, nilai $\mathrm{pH}$ yang terukur di Pantai Tawang dan Pidakan masih berada dalam kisaran toleransi lamun.

Arus dapat memberikan dampak positif terhadap kehidupan biota laut yaitu dengan membawa makanan dan oksigen tetapi dapat pula menyebabkan ketidakseimbangan dasar perairan yang lunak seperti dasar perairan berpasir dan berlumpur. Kecepatan arus perairan di Pantai Tawang sebesar $0,06 \mathrm{~m} / \mathrm{s}$. Ini terjadi karena pada musim-musim pancaroba, angin biasanya lemah dan laut sangat tenang. Faktor yang cukup dominan mempengaruhi gerak arus di perairan Pantai Tawang adalah faktor angin. Di samping itu, dangkalnya perairan dan keberadaan komunitas lamun juga mempunyai pengaruh yang besar dalam memperlambat gerak arus. Arus pasang surut yang tidak begitu kuat menyebabkan vegetasi lamun di Pantai Tawang mudah untuk menancapkan akarnya pada dasar perairan sehingga lamun mudah pula untuk berkembang biak dengan baik. Arus yang tidak kuat ini juga menyebabkan permukaan daun lamun yang tumbuh disana penuh ditumbuhi oleh epifit berikut material lain yang tertampung diantara algae tersebut. Berkebalikan dengan kondisi di Pantai Pidakan, karena arus yang melintas di Pidakan relatif kuat, maka permukaan daun lamun yang tumbuh disana rata-rata bersih. Kecepatan arus perairan di Pantai Pidakan sebesar 0,125 m/s. Arus pasang surut yang kuat menyebabkan vegetasi lamun di Pantai Pidakan sulit untuk menancapkan akarnya pada dasar perairan sehingga lamun sulit pula untuk berkembang biak dengan baik. 
Nutrien yang berpengaruh pada pertumbuhan lamun adalah nitrogen $(\mathrm{N})$ dan fosfor (P). Nitrogen dan fosfor yang terukur di Pantai Tawang dan Pidakan masih berada dalam jumlah yang cukup untuk pertumbuhan lamun. Pengkayaan nutrien (eutrofikasi) dapat memicu pertumbuhan algae epifitik pada daun lamun maupun algae di kolom air. Kedua tipe blooming algae tersebut mengurangi jumlah cahaya yang mencapai lamun. Hal ini mengurangi efektifitas fotosintesis sehingga menekan produktivitas lamun dan menyebabkan penurunan komunitas lamun di seluruh dunia (Papathanasiou et al. 2015; Waycott et al. 2007; Christianen et al. 2011).

Lamun yang tumbuh di Pantai Tawang dan Pidakan berasosiasi dengan berbagai jenis organisme. Akar yang kokoh dan daun lebat merupakan fungsi lamun yang sangat produktif bagi perairan. Akar-akarnya berfungsi sebagai penahan sedimen dari adukan arus, ombak dan badai. Daun-daunnya merupakan pelindung bagi dasar perairan berikut flora dan faunanya dari kekeringan dan sengatan sinar matahari. Beberapa jenis invertebrata yang menghuni padang lamun Pantai Tawang antara lain: Archaster typicus, Echinometra mathaei, Holothuria atra, Nerita chamaeleon, Trochus maculates, Conus textile, Cypraea eglantine, dan Turbo argyrostomus. Sedangkan jenis-jenis algae yang ditemukan antara lain: Padina sp., Ulva sp., dan Halimeda sp. Jenis-jenis invertebrate di Pantai Pidakan antara lain: Tetraclita sp., Archaster typicus, Tripneustes gratilla, Echinometra mathaei, Diadema setosum, Holothuria atra, Ophiarachna affinis, Turbo argyrostomus dan lain sebagainya. Sedangkan jenis-jenis algaenya antara lain: Padina sp., Ulva sp., Actinotrichia fragilis dan lain-lain.

Pada lokasi kajian yang tidak ditumbuhi lamun, transplantasi lamun bisa menjadi solusi karena faktor-faktor fisiko kimia yang terukur di Pantai Klayar, Srau, Teleng Ria dan Pancer sesuai untuk kehidupan lamun. Cara transplantasi lamun belum banyak berkembang di Indonesia namun telah banyak dilakukan oleh para ahli di luar negeri dengan metode dan jenis yang berbeda.

\section{KESIMPULAN}

Hasil penelitian menunjukkan, dari 6 pantai yang diteliti, lamun hanya ditemukan di Pantai Tawang dan Pantai Pidakan. Kekayaan jenis lamun di Pantai Tawang sebanyak tiga jenis, yaitu Thalassia hemprichii, Cymodocea rotundata dan Halophila ovalis. Sedangkan di Pantai Pidakan hanya ditemukan satu jenis lamun yaitu $T$. hemprichii. Nilai C (persentase penutupan) rata-rata sebesar $37,66 \%$ di Pantai Tawang dan 30,89\% di Pantai Pidakan. Berdasarkan Keputusan Menteri Negara Lingkungan Hidup No.200 tahun 2004 nilai tersebut berarti kondisi padang lamun Pantai Tawang dan Pidakan termasuk kategori kurang kaya/kurang sehat.

Faktor-faktor yang menjadi penyebab kurang kayanya persentase penutupan lamun di Pantai Tawang, selain karena faktor alami, juga karena semakin meningkatnya aktivitas manusia dan tingginya kegiatan perahu-perahu nelayan di kawasan ini, sehingga kekeruhan sulit dihindarkan. Sedangkan faktor-faktor yang sangat mempengaruhi penyebaran lamun di Pantai Pidakan adalah substrat atau sedimen, kedalaman, dan ombak.

Hasil pengukuran fisiko kimia yang meliputi kecerahan, temperatur, salinitas, $\mathrm{pH}$, kecepatan arus perairan dan nutrien berupa $\mathrm{NH}_{4}, \mathrm{NO}_{3}, \mathrm{P}_{2} \mathrm{O}_{5}, \mathrm{C}$ organik, bahan organic di lokasi-lokasi yang ditumbuhi lamun (Pantai Tawang dan Pidakan) menunjukkan nilai-nilai yang masih berada dalam kisaran toleransi lamun. Hasil pengukuran fisiko kimia di lokasi-lokasi yang tidak ditumbuhi lamun (Pantai Klayar, Srau, Teleng Ria, Pancer) juga sesuai untuk pertumbuhan lamun sehingga memungkinkan untuk dilakukan transplantasi lamun di lokasi-lokasi tersebut. Padang lamun merupakan ekosistem yang kompleks di perairan dangkal. Lamun Pantai Tawang dan Pidakan berasosiasi dengan berbagai jenis organisme.

\section{UCAPAN TERIMA KASIH}

Terima kasih disampaikan kepada DIKTI yang telah membiayai penelitian ini melalui skim Dosen Pemula pendanaan 2015. Ucapan terima kasih juga disampaikan kepada Anggit 
Sasmito S.Pd. yang telah membantu pengambilan data.

\section{DAFTAR PUSTAKA}

Campbell SJ, McKenzie LJ, Kerville SP. 2006. Photosynthetic Responses of Seven Tropical Seagrasses to Elevated Seawater Temperature. Journal of Experimental Marine Biology and Ecology. vol 330: 455-468.

Christianen MJA, van der Heide T, Bouma TJ, Roelofs JGM, van Katwijk MM, Lamers LPM. 2011. Limited Toxicity of $\mathrm{NH}_{\mathrm{x}}$ Pulses on an early and Late Successional Tropical Seagrass Species: Interactions with $\mathrm{pH}$ and Light Level. Aquatic Toxicology. vol 104: 73-79.

Felisberto P, Jesus SM, Zabel F, Santos R, Silva J, Gobert S, Beer S, Björk M, Mazzuca S, Procaccini G, Runcie JW, Champenois W, Borges AV. 2015. Acoustic Monitoring of $\mathrm{O}_{2}$ Production of a Seagrass Meadow. Journal of Experimental Marine Biology and Ecology. vol 464: 75-87.

Goltenboth F, Schoppe S, Widmann P. 2012. Padang Lamun. Di dalam: Goltenboth, F., K.H. Timotius, P. Po Milan, J. Margraf (eds). Ekologi Asia Tenggara Kepulauan Indonesia. Jakarta: Salemba Teknika. hal 31-46.

Hauxwell J, Cebrian J, Valiela I. 2006. Light Dependence of Zostera marina Annual Growth Dynamics in Estuaries Subject to Different Degrees of Eutrophication. Aquatic Botany. vol 84: 17-25.

Kaldy JE, Shafer DJ, Ailstock MS, Magoun AD. 2015. Effects of Temperature, Salinity and Seed Age on Induction of Zostera japonica germination in North America, USA. Aquatic Botany. vol 126: 73-79.
Kilminster K, Forbes V, Holmer M. 2014. Development of a 'Sediment-Stress' Functional-Level Indicator for the Seagrass Halophila ovalis. Ecological Indicators. vol 36: 280- 289.

Koch MS, Schopmeyer SA, Kyhn-Hansen C, Madden CJ, Peters JS. 2007. Tropical Seagrass Species Tolerance to Hypersalinity Stress. Aquatic Botany. vol 86: 14-24.

Kuo J. 2007. New Monoecious Seagrass of Halophila sulawesii (Hydrocharitaceae) from Indonesia. Short communication. Aquatic Botany. vol 87: 171-175.

Menteri Negara Lingkungan Hidup. 2004. Keputusan Menteri Negara Lingkungan Hidup Nomor: 200 Tahun 2004 Tentang Kriteria Baku Kerusakan dan Pedoman Penentuan Status Padang Lamun. Jakarta: Kementerian Lingkungan Hidup.

Moreno AG, McDonald A, Sherman TD, Lizaso JLS, Heck Jr. KL, Cebrian J. 2014. Short-Term Impacts of Salinity Pulses on Ionic Ratios of The Seagrasses Thalassia testudinum and Halodule wrightii. Aquatic Botany. vol 120: 315-321.

Papathanasiou V, Orfanidis S, Brown MT. 2015. Intra-Specific Responses of Cymodocea nodosa to Macro-Nutrient, Irradiance and Copper Exposure. Journal of Experimental Marine Biology and Ecology. vol 469: 113-122.

Ralph PJ, Durako MJ, Enriquez S, Collier CJ, Doblin MA. 2007. Impact of Light Limitation on Seagrasses. Journal of Experimental Marine Biology and Ecology. vol 350: 176-193.

Waycott M, Collier C, McMahon K, Ralph P, McKenzie L, Udy J, Grech A. 2007. Climate change and the Great Barrier Reef: a vulnerability assesment. Queensland: Department of Primary Industries and Fisheries. 